\title{
Early strength of various fly ash based concrete in peat environment
}

\author{
Monita Olivia $^{1 *}$, Gunawan Wibisono ${ }^{1}$, and Edy Saputra $^{2}$ \\ ${ }^{1}$ Department of Civil Engineering, Universitas Riau, Pekanbaru, Indonesia, \\ ${ }^{2}$ Department of Chemical Engineering, Universitas Riau, Pekanbaru, Indonesia
}

\begin{abstract}
Fly ash is a by-product of coal combustion in a power station and usually used as additive or cement replacement material to improve properties of concrete in aggressive environments such as acid, chloride, and sulphate. Peatland is one of acidic environment that is common in Riau province with high organic content and low $\mathrm{pH}$ that is damaging for concrete, especially when exposed to concrete at an early age. This paper aims to study the early compressive and tensile strength of the various type of fly ash based concrete subjected to peat water. Seven fly ash-based concrete mixtures investigate were, i.e., geopolymer hybrid using $15 \%$ of Ordinary Portland Cement (OPC) as an additive, high volume fly ash using $25 \%, 50 \%$ and $75 \%$ of fly ash as cement replacement material, and blended OPC with fly ash with different grade of 15, 21 and $29 \mathrm{MPa}$. The OPC concrete with a target strength of $20 \mathrm{MPa}$ was a control mix. The OPC based-specimens were cast and cured in water for 28 days before placed in peat water for another 28 days before the testing date. Compressive strength and tensile strength values of the concrete at 7 and 28 days were taken. Results show the type of concrete, fly ash content, and concrete grade significantly influence the early strength properties and resistance of the concrete to the acid attack. Four concrete mixtures with decreasing vulnerability to the attack were distinguished: OPC, high volume fly ash, geopolymer hybrid and blended cement concrete.
\end{abstract}

\section{Introduction}

Degradation due to acidic attack is one of the most significant durability problems of structural concrete. Acid from natural and industrial areas such as organic acid and sulfuric acid is known as the cause of loss strength, and the increase of porosity. The damage occurs when calcium from cement is bound by acid ion and transform its formation into salt that is quickly dissolved [1].

Riau province has approximately 4 million hectares peatland [2]. Fast-growing regency cities in Riau require a large number of infrastructure that could be built in the peatland. The peat has a disadvantage such as high organic content, high water content, low $\mathrm{pH}$ and low bearing capacity [3] and can be improved by consolidation, stabilization, and cut and

*Corresponding author: monita.olivia@lecturer.unri.ac.id 
fill. In the long term, continuous degradation will cause premature deterioration and reduction of serviceability of structures in peatland.

Improvement of concrete in peatland could be achieved by the inclusion of pozzolanic materials and reduction of the calcium content in concrete. Fly ash, silica fume, Palm Oil Fuel Ash (POFA), and Rice Husk Ash (RHA) are some pozzolanic materials used in concrete. Previous studies show that concrete with $10-25 \%$ pozzolanic materials as a cement replacement to produce better resistance than OPC concrete in acidic peat condition $[4,5]$. Previous studies of concrete in peatland environment suggested that pozzolanic material inclusion is critical since sole binder such as Ordinary Portland Cement cannot be used in such an aggressive environment. Calcium-silicate-hydrate $(\mathrm{CSH})$ produced by OPC hydration product with pozzolanic materials in concrete increase density and chemical resistance to acidic attack $[1,6]$.

Fly ash is available abundantly in Riau province as a by-product from industries and a coal power station in the region. Fly ash has been used as partial, high volume and full cement replacement material to optimize utilization of the material. As a partial replacement, the fly ash content in the range of $10-25 \%$ was used in concrete for specific purposes in an aggressive environment. Strength properties decrease with the increase of fly ash content in the concrete. However, high volume fly ash that uses more than $40 \%$ but up to $60 \%$ of fly ash in the mixture could be designed to have a strength of more than $30 \mathrm{MPa}$ with a good durability $[7,8]$.

Another type of concrete that uses full replacement of fly ash is known as geopolymer. Geopolymer is produced by activating fly ash with high silicate materials that could bind aggregates as concrete. Geopolymer concrete has higher resistance to chloride, acid, sulfate and high temperature than the OPC concrete $[9,10]$. The previous study shows that fly ash geopolymeric material in peat environment was transformed into different material with moderate resistance to acid attack. However, geopolymer needs high temperature to increase reaction to refine porosity and improve the strength of concrete. This method is impractical in the application; thus many studies recommended inclusion of slag and OPC to assist curing in ambient temperature $[11,12]$. The geopolymer hybrid concrete provides comparable qualities with geopolymer cured in higher temperature [13].

Early strength is an indicator of strength development before 28 days. Blended cement has different strength development against the acidic peat environment, and its effect has not known yet. The study aims to provide more data on the impact of various types of fly ash concrete on the resistance of concrete against the acidic environment. In this research, the early strength of blended cement and geopolymer was investigated.

\section{Materials and methods}

Fly ash from Ombilin coal power station West Sumatra was used in this study. Ordinary Portland Cement (OPC) is used as the primary material for blended cement and an additive for geopolymer concrete. Aggregates from local quarries, fine aggregate has a modulus of fineness of 2.6 and specific gravity of 2.75 , while coarse aggregate with a specific gravity of 2.70 and absorption of $1.5 \%$. Table 1 presents the chemical composition of OPC and fly ash.

Seven concrete mixtures with three different groups were prepared. First, fly ash geopolymer mix with OPC as an additive of $15 \%$. Second, blended cement concrete with fly ash as cement replacement material of $25 \%, 50 \%$ and $75 \%$ (high volume blended fly ash). Third, blended cement concrete with the fly ash of $25 \%$ and grade 15,21 and $29 \mathrm{MPa}$. OPC with a target strength of $20 \mathrm{MPa}$ was used as a control mix. Fly ash geopolymer was prepared using alkaline solution consists of $\mathrm{NaOH}$ and sodium silicate with $\mathrm{Ms}=2.30$. Superplasticizer was added to improve the workability of the geopolymer mixture. 
Superplasticizer with the percentage of $0.75-1.5 \%$ per weight of cement was used for high volume fly ash (HVFA) concrete. Mixture composition of fly ash based concrete could be seen in Table 2.

Table 1. Chemical composition of Ordinary Portland Cement and fly ash.

\begin{tabular}{|c|c|c|}
\hline Chemical composition & OPC (\%)* & Fly ash (\%) \\
\hline Silicone Dioxide $\left(\mathrm{SiO}_{2}\right)$ & 20.92 & 59.25 \\
\hline Aluminium Trioxide $\left(\mathrm{Al}_{2} \mathrm{O}_{3}\right)$ & 5.49 & 29.25 \\
\hline Iron Trioxide $\left(\mathrm{Fe}_{2} \mathrm{O}_{3}\right)$ & 3.78 & 5.45 \\
\hline Titanium Dioxide $\left(\mathrm{TiO}_{2}\right)$ & - & 0.83 \\
\hline Calcium Oxide $(\mathrm{CaO})$ & 65.21 & 1.54 \\
\hline Magnesium Oxide $(\mathrm{MgO})$ & - & 0.31 \\
\hline Potassium Oxide $\left(\mathrm{K}_{2} \mathrm{O}\right)$ & - & 2.23 \\
\hline Sodium Oxide $\left(\mathrm{Na}_{21} \mathrm{O}\right)$ & - & 0.68 \\
\hline Phosphorus Pentoxide $\left(\mathrm{P}_{2} \mathrm{O}_{5}\right)$ & - & 0.04 \\
\hline Sulphur Trioxide $\left(\mathrm{SO}_{3}\right)$ & - & 0.29 \\
\hline Manganese Dioxide $\left(\mathrm{MnO}_{2}\right)$ & - & 0.01 \\
\hline Moisture content $(\%)$ & - & 18.89 \\
\hline Loss On Ignition $(\mathrm{LOI})(\%)$ & - & 0.25 \\
\hline
\end{tabular}

Table 2. Mixture composition of concrete

\begin{tabular}{|c|c|c|c|c|c|c|c|c|}
\hline \multirow{2}{*}{ Mixes } & \multicolumn{7}{|c|}{ Quantity per $\mathbf{m}^{3}$ (kg) } \\
\cline { 2 - 9 } & OPC & $\begin{array}{c}\text { Fly } \\
\text { ash }\end{array}$ & $\begin{array}{c}\text { Fine } \\
\text { agg. }\end{array}$ & $\begin{array}{c}\text { Coarse } \\
\text { agg. }\end{array}$ & Water & NaOH & Na2SiO $_{3}$ & SP \\
\hline OPC & 350.88 & - & 829.96 & 930.86 & 224.01 & - & - & - \\
\hline GP & 76.83 & 512.20 & 546 & 1014 & 120 & 109.27 & 218.54 & 7.68 \\
\hline FA_25 & 202.70 & 44.83 & 882.10 & 932.73 & 227.40 & - & - & - \\
\hline FA_50 & 175.44 & 116.40 & 814.81 & 932.73 & 225.36 & - & - & - \\
\hline FA_75 & 87.72 & 174.60 & 814.81 & 932.73 & 225.36 & - & - & - \\
\hline OPC_15 & 202.70 & 44.83 & 882.10 & 932.73 & 227.40 & - & - & - \\
\hline OPC_21 & 263.16 & 58.20 & 814.81 & 932.73 & 225.36 & - & - & - \\
\hline OPC_29 & 340.91 & 75.40 & 724.67 & 932.73 & 219.14 & - & - & - \\
\hline
\end{tabular}


Specimens were manufactured using two methods. Fly ash geopolymer concrete was prepared by mixing fly ash, aggregates, with alkaline solutions and OPC. The high volume fly ash was prepared by using different fly ash content up to $75 \%$, and the blended cement was made by using different concrete grade. The fly ash geopolymer was cured in ambient curing or room temperature curing and subsequently immersed in peat water. Blended cement was cured in water for 28 days before put in the peat water up to 28 days.

Early strength was measure by a change in compressive strength and a difference in tensile strength. Compressive strength was taken at 28 days after curing in water, and at 7 and 28 days after immersed in peat water. Specimens were cylindrical with a dimension of $15 \times 30 \mathrm{~cm}$ and $10 \times 20 \mathrm{~cm}$. Compressive strength and tensile strength were tested according to SNI 1989, respectively.

\section{Results and discussion}

Table 3 shows the compressive strength development of various concrete mixing at 0,7 and 28 days. At seven days, the compressive strength of all concrete was in the range of 6.74$30.22 \mathrm{MPa}$. It can be seen that the compressive strength increased with concrete age for all concrete except for the OPC mixture. The geopolymer (GP) displayed a slow gain of early age strength until 28 days. Although it is still developing, the early strength reached 20.60 $\mathrm{MPa}$ at 28 days. This shows that the geopolymer has an excellent early strength development although in peat environment.

Table 3. Compressive strength of concrete

\begin{tabular}{|c|c|c|c|c|c|c|}
\hline \multirow{2}{*}{ Mixtures } & \multicolumn{6}{|c|}{ Compressive strength (MPa) } \\
\cline { 2 - 7 } & 0 day & SD & 7 days & SD & 28 days & SD \\
\hline OPC & 21.75 & 0.88 & 22.71 & 1.76 & 20.21 & 1.53 \\
\hline GP & 15.59 & 1.53 & 16.75 & 0.58 & 20.60 & 0.67 \\
\hline FA_25 & 19.64 & 1.53 & 21.17 & 1.77 & 21.37 & 0.58 \\
\hline FA_50 & 11.16 & 0.89 & 12.90 & 1.20 & 14.63 & 0.88 \\
\hline FA_75 & 5.58 & 0.33 & 6.74 & 0.89 & 9.43 & 0.33 \\
\hline OPC_15 & 13.86 & 0.58 & 14.63 & 0.88 & 14.82 & 1.20 \\
\hline OPC_21 & 19.64 & 1.53 & 21.17 & 1.77 & 21.37 & 0.58 \\
\hline OPC_29 & 28.87 & 0.58 & 30.22 & 0.88 & 32.34 & 0.58 \\
\hline
\end{tabular}

Mixes FA_25, FA_50, and FA_75 or high volume fly ash concrete compared to the OPC had lowest strength gain. There was a strength reduction at 0 days by replacing more fly ash into the concrete up to $75 \%$. However, after immersed into the peat water there was still a strength gain occurs up to 28 days. In practical, a replacement of fly ash in a high volume is beneficial to reduce vast quantity of fly ash in a landfill. Although there was a low strength gain for both FA_50 and FA_75, the strength development by 5-10\% after immersed in peat water makes this concrete promising for application in peatland. Replacement of high volume fly ash is considered still acceptable for low strength purpose concrete imposed to acidic peat environment. 
Concrete grade could improve concrete early strength performance in acidic environment. From Table 3 it could be seen that the strength gain was increased up to 28 days after immersed in peat water. Replacement of $25 \%$ fly ash is beneficial to reduce the potential of severe acidic attack, while at the same time a strength gain was highly improved after 0 days. In practical, the fly ash is usually incorporated around $20-30 \%$ since its strength gain at an early age is very low. However, this is more noticeable for low strength concrete (OPC_15) than the higher strength concrete (OPC_29).

Tensile strength usually is very small compared to compressive strength. It is also an indicator of good adhesion between aggregate and cement paste. Table 4 presents the variety of tensile strength of concrete after immersed in peat water up to 28 days. It could be seen that the geopolymer, FA_50, and OPC_15 has quite similar tensile strength compared to other types of concrete. This is because of the target strength of around 11-15 $\mathrm{MPa}$ at 0 day. However, there was a significant increase at 28 days for GP and OPC_15, where the tensile strength was approximately 2.06-2.07. There was not strength development for FA_50 compared to both concrete.

Table 4. Tensile strength of concrete

\begin{tabular}{|c|c|c|c|c|c|c|}
\hline \multirow{2}{*}{ Mixtures } & \multicolumn{6}{|c|}{ Tensile strength (MPa) } \\
\cline { 2 - 7 } & 0 day & SD & 7 days & SD & 28 days & SD \\
\hline OPC & 2.60 & 0.11 & 2.56 & 0.09 & 2.03 & 0.04 \\
\hline GP & 1.57 & 0.27 & 1.64 & 0.20 & 2.06 & 0.17 \\
\hline FA_25 & 2.33 & 0.08 & 2.43 & 0.11 & 2.55 & 0.08 \\
\hline FA_50 & 1.32 & 0.18 & 1.42 & 0.25 & 1.77 & 0.25 \\
\hline FA_75 & 0.52 & 0.04 & 0.62 & 0.04 & 1.06 & 0.19 \\
\hline OPC_15 & 1.82 & 0.11 & 1.98 & 0.07 & 2.07 & 0.11 \\
\hline OPC_21 & 2.33 & 0.08 & 2.43 & 0.11 & 2.55 & 0.07 \\
\hline OPC_29 & 2.69 & 0.07 & 2.78 & 0.11 & 2.92 & 0.11 \\
\hline
\end{tabular}

OPC_29 and OPC had a higher tensile strength at the beginning of the test. However, the tensile strength of OPC was reduced at 28 days, given the tensile strength of OPC_29 increased to $2.92 \mathrm{MPa}$. The effect of acidic environment is significant to reduce the tensile strength of concrete at an early age. The impact of pozzolanic material is essential since it will enhance the cement paste adhesion with the aggregates.

On the contrary, FA_50 and FA_75 show the highest gain of the tensile strength of 0.5 $\mathrm{MPa}$ at 28 days. Adhesion between high volume fly ash concrete with aggregate could be a reason why these values increased significantly. High volume fly ash could act as microaggregate and fill the Interfacial Transition Zone and reduce the area between aggregate and cement paste. This affected the tensile strength positively by improving the early tensile strength of the concrete.

Tensile strength variation with the compressive for OPC and geopolymer hybrid is presented in Figure 1. As the strength increased, the tensile strength of OPC and geopolymer concrete also has increased correspondingly. In contrast, OPC has higher tensile strength than the geopolymer as the corresponding compressive strength was also higher than the geopolymer concrete. This is might be due to better adhesion between 
aggregate and cement paste in OPC concrete. Fly ash geopolymer from Ombilin has high LOI (around $18.89 \%$ ). High LOI pozzolanic material usually affect the bonding between hydration products and the aggregates. High LOI means high unburnt carbon particles when react with the cement hydration product will results in a weaker matrix. This is disadvantageous because in aggressive environment such organic peat acid, a stronger matrix will enhance durability properties of the concrete.

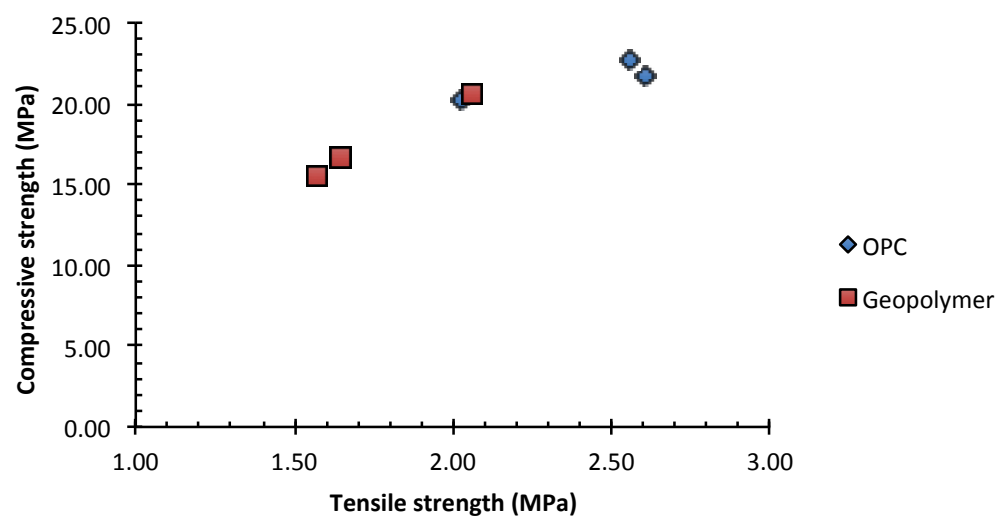

Fig. 1. Tensile strength variation with the compressive strength of OPC and geopolymer concrete.

In Figure 2 the tensile strength variation of OPC and high volume fly ash concrete is presented. It can be seen that the tensile strength increased with the compressive strength. FA_75 has the lowest tensile strength compared to other data. This is because the tensile strength of high volume fly ash is much smaller than the other type of concrete, due to weak bonding between the cement paste and aggregate. A similar trend could be seen in Figure 3. Concrete grade influences the tensile strength because of better bonding between the concrete ingredients.

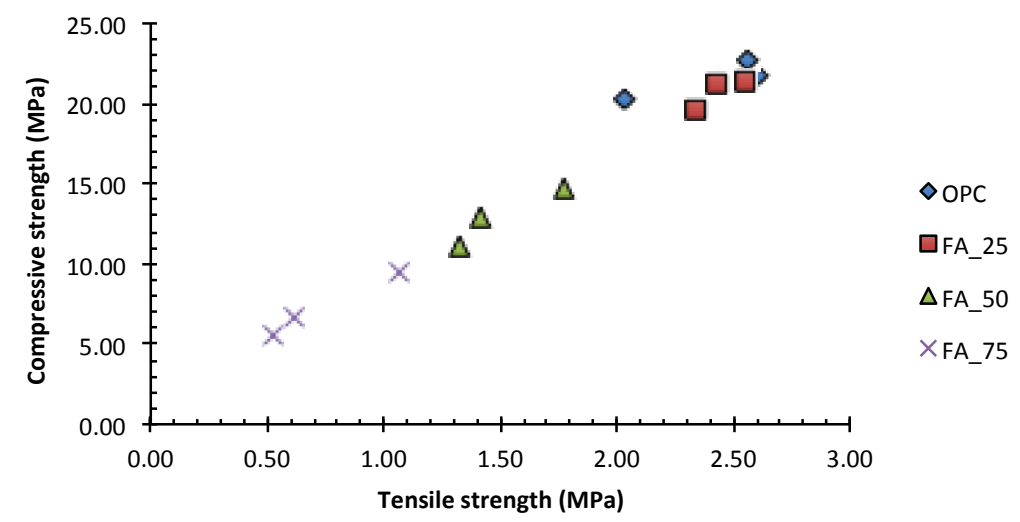

Fig. 2. Tensile strength variation with the compressive strength of OPC and high volume fly ash concrete.

The inclusion of fly ash in concrete is beneficial to enhance durability in the long term. However, fly ash concrete type determine the vulnerability of concrete in an aggressive environment. Based on the study, blended cement concrete has the highest early strength compared to another type, followed by geopolymer hybrid, high volume fly ash, and the 
control OPC concrete. Blended concrete with approximately $25 \%$ cement replacement has a high OPC content than other fly ash concrete, thus results in better early strength development. The strength development of geopolymer hybrid in early age depends mostly on the OPC hydration. High volume fly ash concrete showed lower strength development than other fly ash concrete type due to the vast amount of OPC replacement in concrete. The early strength development was delayed with a slow matrix transformation and high pozzolanic material content in the mixture. Judging from the study, the speed of matrix formation in concrete determine the early strength of concrete, thus the resistance of concrete in the peat water environment.

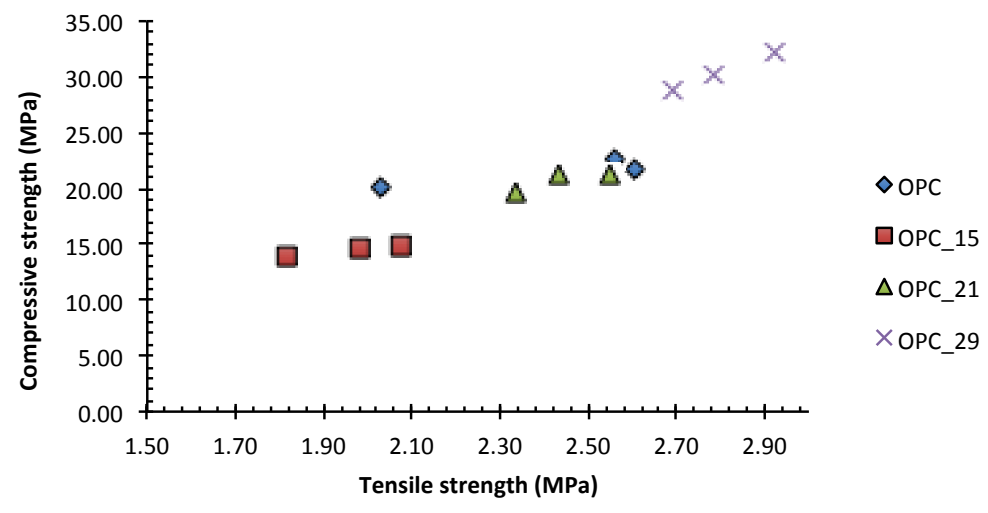

Fig. 3. Tensile strength variation with the compressive strength of OPC and blended concrete.

\section{Conclusions}

Fly ash is a product of coal combustion in a power station and usually used as additive or cement replacement material to improve properties of concrete in the long term. In this paper, the early strength of the various type of fly ash based concrete subjected to peat water was investigated. Seven fly ash-based concrete mixtures were studied, i.e., geopolymer hybrid using $15 \%$ of OPC as an additive, high volume fly ash using $25 \%, 50 \%$ and $75 \%$ of fly ash as cement replacement material, and blended OPC with fly ash with different grade of 15, 21 and $29 \mathrm{MPa}$. Results show the type of concrete, fly ash content, and concrete grade had a significant influence on early strength properties and improved the resistance of the concrete to the acid attack. Four concrete mixtures with decreasing vulnerability to the attack were distinguished: OPC, high volume fly ash, geopolymer hybrid and blended cement concrete.

Authors acknowledged the support/funding from DRPM Penelitian Berbasis Kompetensi 2018 Kemenristekdikti Contract No. 361/UN.19.5.13/PP//2018.

\section{References}

1. V. Zivica, Con. Build. Mat. 20 (2006)

2. F. Agus, I.G.M. Subiksa, Lahan gambut: Potensi untuk pertanian dan aspek lingkungan (Balai Penelitian Tanah Badan Penelitian dan World Agroforesty Centre, Bogor, 2008).

3. S. Kazemian, S, B.B.K. Huat, T.A. Mohammed, F.N.A.A. Aziz, H. Moayedi, M. Barghchi, Arab J. Sci. and Eng. 36 (2011) 
4. M. Olivia, U.A. Hutapea, I.R. Sitompul, L. Darmayanti, A. Kamaldi, Z. Djauhari, 2104. Proceedings of the $6^{\text {th }}$ International Conference of Asian Concrete Federation (2014)

5. M. Olivia, T. Pradana, I.R. Sitompul, Procedia Engineering 171 (2017)

6. O. Oueslati, J. Duchesne, Cem. Con. Comp. 45 (2014)

7. T. Hemalatha, A. Ramaswamy, J. Cleaner. Prod. 147 (2017)

8. A. Oner, S. Akyuz, R. Yildiz, Cem. Con. Res. 35 (2005)

9. J.L. Provis, S.A. Bernal, J. Sustainable Cement-Based Mat. 4 (2014)

10. M. Olivia, H. Nikraz, Proc. of the Concrete 11 Conference (2011)

11. P.S. Deb, P. Nath, P.K. Sarker P.K. Materials and Design 62 (2014)

12. P. Nath, P.K. Sarker, Cem. Concrete Comp. 55 (2015)

13. I. Garcia-Lodeiro, S. Donatello, A. Fernandez-Jimenez, A. Palomo, Materials 9 (2016) 